\title{
Litterfall and Litter Decomposition in Pinus and Native Forests
}

\author{
Flávia Ferreira de Carvalho ${ }^{1}$ (D), Patrícia Anjos Bittencourt Barreto-Garcia ${ }^{1}$ (D), \\ Mariana Aquino Aragão ${ }^{2}$ (D), Aline Pereira das Virgens ${ }^{1}$
}

${ }^{1}$ Departamento de Engenharia Agrícola e Solos, Universidade Estadual do Sudoeste da Bahia - UESB, Vitoria da Conquista/BA, Brasil

${ }^{2}$ Departamento de Ciências Florestais e da Madeira, Universidade Federal do Espirito Santo - UFES, Jerônimo Monteiro/ES, Brasil

\begin{abstract}
Litter production and decomposition makes it possible to supply a good part of the nutrient demand of forest stands. Although several studies on this subject have been carried out in Pinus stands in different regions of Brazil, there are no records of studies carried out in the Northeast region, or in particular in the state of Bahia. Therefore, the objective of this work was to evaluate the litter production (litterfall) and decomposition in Pinus stands in the southwest region of Bahia, using an area of native forest as reference. Litterfall was evaluated during twelve months with the use of suspended collectors. Litter accumulation was quantified by means of three collections. The values obtained from litterfall were similar among Pinus stands. However, these values were lower than those found in the reference forest and in stands of the same genus in other regions of Brazil. Litter decomposition is relatively slow in Pinus sp. stands. The temporal variation of the litter supply is not very sensitive to the climate variations.
\end{abstract}

Keywords: Reforestation, deposition, production, senescent material. 


\section{INTRODUCTION}

The forestry sector in Brazil has grown in the last decades. The progressive demand for products and by-products of forest origin such as oils, essences, and especially wood have provided a large increase in the number of reforestation areas with exotic fast-growing species (ABRAF, 2013). A typical example of this trend is the Pinus genus, the main source of raw material for several industries in the country, which has its most extensive plantations established in the states of Paraná and Santa Catarina, although it is also distributed in several other regions of the country, including the Northeast region (IBÁ, 2015).

According to the Brazilian Agricultural Research Corporation (Empresa Brasileira de Pesquisa Agropecuária - EMBRAPA, 2014), the Pinus genus comprises more than 100 species with great potential for several purposes. Its wood is mainly used in sawing and laminating, sheet metal, and pulp and paper industries. The main characteristics that have led to the wide use of this genus are wood quality, rusticity and tolerance, which enable its planting in soils which are marginal to agriculture (Chaves \& Corrêa, 2005). In addition to the use of wood for various purposes, Pinus species excel in the production of resin used in glue, varnish, paint and adhesive industries (Medeiros et al., 2017).

Native or planted forests such as Pinus plantations present a continuous supply of senescent material from its aerial parts and root system, which favors the formation of an organic layer on the soil surface, also known as litter. According to Vieira \& Shumacher (2010a), plant litter consists of vegetable debris (leaves, branches, stems, bark, fruit and flowers) and animal debris. This layer plays an important role in maintaining or increasing the production of forest ecosystems, since it allows a return of nutrients and carbon from the vegetal biomass into the soil through decomposition (Giácomo et al., 2012; Godinho et al., 2013; Pinto et al., 2016). It also plays an important role in the interception and retention of rainwater, thus contributing to an increase in the infiltration rate and water storage in the soil (Mateus et al., 2013). Therefore, plant litter together with the aerial and root parts of plants provide protection to the soil and can provide conditions for reestablishing its physical, chemical and biological properties (Andrade et al., 2000).
The presence of litter on the surface of forest soils and its consequent reuse in nutrient cycling, along with the decomposition process, enables the supply of a large part of the trees' nutrient demands, thus guaranteeing an ecosystem functioning. The importance of this process is evidenced in forests found growing in soils of low fertility (Schumacher et al., 2003), which is the case of the great majority of areas planted with fast growing exotic forest species such as the Pinus genus in Brazil.

Although nutrient cycling is a common process for all forest ecosystems, the amount of litter produced and its decomposition rate are particular to each ecosystem. This pattern is determined by vegetation characteristics such as species composition and the quality of plant residue, in addition to the action of climatic variables which may alter the amount of litter deposited and advance (or not) its decomposition (Vieira \& Shumacher, 2010b; Barbosa et al., 2017).

Several studies on litterfall and litter decomposition of Pinus stands have been carried out in different regions of Brazil (Carvalho et al., 2008; Schumacher et al., 2008; Vieira \& Shumacher, 2010a; Piovesan et al., 2012; Lima et al., 2015). However, there are no records in the literature of studies carried out in the Northeast region, or in particular in the state of Bahia.

In view of the above, the present study had the objective to evaluate the litterfall and litter decomposition in two Pinus stands; a pure stand (Pinus caribaea), and another among a consortium (Pinus oocarpa, Pinus caribaea and Pinus taeda), both in the Southwest region of Bahia, as well as considering the possible interference of climatic variables. A semi-deciduous seasonal forest was used as a reference. Therefore, it was assumed that the dynamics of litterfall (production) and litter decomposition would differ according to the organization of the Pinus sp. stands (homogeneous or heterogeneous) and their climatic conditions.

\section{MATERIAL AND METHODS}

\subsection{Characterization of the area}

The studied areas are located in the experimental area of the State University of Southwest of Bahia, Campus of Vitória da Conquista, at the geographic coordinates of $14^{\circ} 53^{\prime}$ latitude south and $40^{\circ} 48^{\prime}$ longitude west. The climate of the region is subtropical highland (Cwb) according to the Köppen classification, with an annual 
average temperature of $21^{\circ} \mathrm{C}$ and precipitation between $700 \mathrm{~mm}$ and $1100 \mathrm{~mm}$. The region has an altitude of around $880 \mathrm{~m}$. The soils of the studied areas have a clayey texture and belong to the single class of Dystrophic Yellow Latosol (Santos et al., 2006). Table 1 shows the chemical characterization of these soils at a depth of $0-10 \mathrm{~cm}$.

The study was conducted in two Pinus stands, one in consortium (composed of three species: Pinus caribaea, Pinus oocarpa, and Pinus taeda), and another stand purely composed of Pinus caribaea var. hondurensis. Each stand has an area of approximately 0.5 ha and is about 11 years old. A fragment of Semi-deciduous Seasonal Forest, regionally known as mata-de-cipó, was used as reference.

The Pinus stands were implanted in an area of lower capoeira vegetation after the area had been cleared using a crawler tractor and the soil harrowed. Planting was carried out in 2002 with seminal seedlings and pit fertilization (200 grams of Simple Superphosphate), according to a $3 \mathrm{~m} \times 3 \mathrm{~m}$ spacing. Stand maintenance was carried out at two, six and twelve months after planting, with weed-competition control by weeding the lines and between the rows. According to measurements made in June 2013 in the Pinus stand consortium, the diameter at breast height $(\mathrm{DBH})$ of the trees varied from 13.2 to $25.0 \mathrm{~cm}$ for Pinus oocarpa, between 13.8 and $25.5 \mathrm{~cm}$ for Pinus caribaea, and between 5.0 and $13.7 \mathrm{~cm}$ for Pinus taeda. In pure stand, the Pinus caribaea trees presented a DBH between 11.9 and $23.9 \mathrm{~cm}$.

The reference fragment has an area of 42 hectares and is in the middle stage of ecological succession according to criteria established by Brasil (1994). The vegetation consists of partially deciduous woody plants surrounded by lianas, with height varying between 10 and $20 \mathrm{~m}$ and an ecotype predominance of the Leguminosae family, with the genus Parapiptadenia being highlighted (IBGE, 2012).

\subsection{Litterfall production}

Wooden collector trays of $0.5 \mathrm{~m} \times 0.5 \mathrm{~m}\left(0.25 \mathrm{~m}^{2}\right)$ suspended $15 \mathrm{~cm}$ away from the soil surface and with $1 \mathrm{~mm}$ nylon mesh bottom were used. Twelve (12) collectors were randomly distributed in each of the Pinus stands in four $15 \mathrm{~m} \times 15 \mathrm{~m}$ plots (three collectors per plot), which were also randomly demarcated. A $1,000 \mathrm{~m}^{2}(100 \times 100 \mathrm{~m})$ plot was established in the Semi-deciduous Seasonal Forest fragment where four collectors were randomly installed, as described by Gama-Rodrigues \& Barros (2002).

The litter intercepted by the collectors was collected monthly during twelve months (from June 2013 to May 2014). The litter was sorted after each collection into: leaves, reproductive structures, bark and branches. After sorting the samples, the fractions were oven dried (at $60{ }^{\circ} \mathrm{C}$ for 72 hours) and then weighed.

Based on the dry mass results of the fractions, the monthly and total production of forest ecosystems were calculated according to the following formulas:

$\operatorname{Prod}_{\text {month } / \text { ha }}=\frac{\left(\operatorname{Prod}_{\text {month }} * 10.000\right)}{A_{C}} \operatorname{Prod}_{\text {total } / \text { a }}=\sum \operatorname{Prod}_{\text {month } / \text { ha }}$

In which: Prod $_{\text {month }}=$ Litterfall contribution obtained in each month $\left(\mathrm{kg} \mathrm{\text {month}^{-1 } )}\right.$; $\operatorname{Prod}_{\text {month/ha }}=$ Monthly contribution of litterfall per hectare $\left(\mathrm{kg} \mathrm{ha}^{-1} \mathrm{month}^{-1}\right)$; Ac $=$ Collector Area $\left(\mathrm{m}^{2}\right) ; \operatorname{Prod}_{\text {total } / \mathrm{ha}}=$ Total amount of litterfall $\left(\mathrm{kg} \mathrm{ha}^{-1}\right)$.

\subsection{Accumulated litterfall}

The amount of litterfall accumulated on the soil surface was estimated using a $0.5 \times 0.5 \mathrm{~m}\left(0.25 \mathrm{~m}^{2}\right)$ square wooden frame, which was randomly launched with four replicates in each area. Three collections were performed: one in the first month of the experiment, the second six months after the beginning, and the last at the end of the twelve months. All deciduous plant

Table 1. Chemical characterization of the soil $(0-10 \mathrm{~cm}$ depth).

\begin{tabular}{|c|c|c|c|c|c|c|c|c|c|c|}
\hline \multirow{2}{*}{ Cover } & pH & $\mathbf{O M}$ & $\mathbf{P}$ & $\mathbf{K}$ & $\mathrm{Ca}$ & $\mathrm{Mg}$ & $\mathbf{H}+\mathbf{A l}$ & Al & $\mathbf{V}$ & $\mathbf{M}$ \\
\hline & & $\mathrm{g} \mathrm{dm}^{-3}$ & $\mathrm{mg} \mathrm{dm}^{-3}$ & \multicolumn{5}{|c|}{$-----\mathrm{cmolc} \mathrm{dm}^{3}-----$} & \multicolumn{2}{|c|}{- - \%-— } \\
\hline Pinus in consortium* & 5.1 & 20 & 1.0 & 0.23 & 1.0 & 0.9 & 3.8 & 0.3 & 36 & 12 \\
\hline Pinus caribaea & 4.7 & 18 & 1.0 & 0.14 & 1.0 & 1.0 & 4.8 & 0.8 & 27 & 31 \\
\hline Native forest & 4.9 & 36 & 3.0 & 0.17 & 3.2 & 1.4 & 5.8 & 0.3 & 45 & 6 \\
\hline
\end{tabular}

${ }^{*}$ Pinus in consortium - Pinus caribaea, Pinus oocarpa, Pinus taeda; RS = Reproductive structures; Analyses performed according to EMBRAPA (1997): $\mathrm{pH}$ (water); extractable $\mathrm{P}$ and $\mathrm{K}$ by Mehlich-1; exchangeable $\mathrm{Ca}, \mathrm{Mg}$ and $\mathrm{Al}$ by $\mathrm{KCl} 1 \mathrm{~mol} \mathrm{~L}^{-1}$ and organic matter $(\mathrm{OM})$ by oxidation with $\mathrm{Na}_{2} \mathrm{Cr}_{2} \mathrm{O}_{7} 4 \mathrm{~N}$. Soil samples were collected at a depth of $0-10 \mathrm{~cm}$, with four replicates, one per each $15 \times 15 \mathrm{~m}$ plot. Each replicate consisted of a sample composed of 20 simple samples. V-base saturation and $\mathrm{m}$-saturation by aluminum. 
material deposited on the soil and circumscribed to the frame at different degrees of decomposition was considered as accumulated litter. The same drying and weighing procedure used for the estimation of litter deposited on the collectors was adopted.

\subsection{Decomposition rate}

The equation proposed by Olson (1963) was used to estimate the litter decomposition rate: $\mathrm{K}=\mathrm{L} / \mathrm{X}$, in which $\mathrm{K}$ = coefficient of decomposition in the condition of dynamic equilibrium, $\mathrm{L}=$ annual litterfall production $\left(\mathrm{kg} \mathrm{ha}^{-1}\right)$, and $\mathrm{X}=$ annual average accumulated litter $\left(\mathrm{kg} \mathrm{ha}^{-1}\right)$. Based on the $\mathrm{K}$ value, the mean renewal time $\left(\mathrm{T}_{\mathrm{R}}\right)$ of accumulated litter on the soil was estimated by the relationship $1 / \mathrm{K}$, and the half-life $\left(\mathrm{T}_{0.5}\right)$; moreover, the time required for $50 \%$ litter decomposition to occur was found using the equation $\mathrm{T}_{0.5}=-\operatorname{Ln} 0.5 / \mathrm{K}$, as proposed by Shanks \& Olson (1961).

\subsection{Climate variables}

The climatic variables of precipitation, temperature, wind speed and relative humidity were considered to assess the influence of climate on litterfall production. The data corresponding to the study period (from June 2013 to May 2014) were made available by the Meteorological Station of the State University of Southwest of Bahia (ESMET), as shown in Table 2.

\subsection{Statistical analyses}

The data were submitted to normality analysis (Lilliefors test) and homogeneity of variance of error (Cochran and Bartlett test). Analysis of variance according to a completely randomized design with four replications was performed for parametric data, while the Tukey test at $5 \%$ significance was adopted to compare means between forest ecosystems and litter fractions.

In order to evaluate the influence of climatic factors on litterfall production over the study period, Pearson correlations at $5 \%$ significance were established between litter deposition and climatic variables (precipitation, temperature, wind speed and relative humidity). All statistical analyses were carried out using the statistical program SAEG v.9.1.

\section{RESULTS AND DISCUSSION}

\subsection{Litterfall production}

The average monthly litterfall production of Pinus stands was $213.7 \mathrm{~kg} \mathrm{ha}^{-1}$ month $^{-1}$. This value is similar to that observed by Vieira \& Shumacher (2010a) in a pure stand of Pinus taeda at 11 years of age in Cambará (RS) (212.1 kg ha ${ }^{-1}$ month $^{-1}$ ); however, it is lower than that found by Melo \& Resck (2002) in studying Pinus caribaea stands at 16 years of age in the Cerrado region, who found a deposition rate of $868.25 \mathrm{~kg} \mathrm{ha}^{-1}$ month $^{-1}$ for the hondurensis variety,

Table 2. Climatic data of the study period in Vitória da Conquista, Bahia state, Brazil. Data provided by the Meteorological Station of the State University of Southwest Bahia (ESMET).

\begin{tabular}{|c|c|c|c|c|}
\hline \multirow{3}{*}{ Months } & \multicolumn{4}{|c|}{ Climate Variables } \\
\hline & Precipitation & Average temperature & Wind speed & Relative humidity \\
\hline & $\mathbf{m m}$ & ${ }^{\circ} \mathrm{C}$ & $\mathrm{m} \mathrm{s}^{-1}$ & $\%$ \\
\hline June 2013 & 35.30 & 19.78 & 1.71 & 87.30 \\
\hline July 2013 & 17.10 & 19.36 & 1.98 & 84.35 \\
\hline August 2013 & 19.30 & 19.46 & 2.59 & 80.69 \\
\hline September 2013 & 20.80 & 21.01 & 2.61 & 78.13 \\
\hline October 2013 & 29.30 & 21.68 & 2.82 & 75.09 \\
\hline November 2013 & 33.20 & 23.10 & 2.51 & 69.13 \\
\hline December 2013 & 231.70 & 23.06 & 1.55 & 77.72 \\
\hline January 2014 & 69.60 & 22.17 & 2.45 & 76.57 \\
\hline February 2014 & 35.30 & 20.81 & 2.50 & 77.25 \\
\hline March 2014 & 37.00 & 23.00 & 2.03 & 75.04 \\
\hline April 2014 & 42.00 & 22.94 & 2.20 & 71.78 \\
\hline May 2014 & 42.00 & 21.67 & 1.63 & 72.51 \\
\hline
\end{tabular}


and $596.8 \mathrm{~kg} \mathrm{ha}^{-1}$ month $^{-1}$ for the bahamensis variety. Poggiani (1987) also verified a higher result in plantations of the Pinus genus at 11 years of age in Agudos (SP), where contributions of $700.0 \mathrm{~kg} \mathrm{ha}^{-1} \mathrm{month}^{-1}$ for Pinus caribaea var. hondurensis, and of $591.7 \mathrm{~kg} \mathrm{ha}^{-1}$ month $^{-1}$ for Pinus oocarpa were found.

The average monthly litter contribution of the native forest was $527.4 \mathrm{~kg} \mathrm{ha}^{-1} \mathrm{month}^{-1}$. This result is similar to that observed by Santos Neto et al. (2015) in the Semi-deciduous Seasonal Forest located in the same municipality where the present study was carried out (544.6 kg ha-1 month $^{-1}$ ). On the other hand, Pinto et al. (2008) found a higher value in a Semi-deciduous Seasonal Forest in Viçosa (MG) (735.0 $\left.\mathrm{kg} \mathrm{ha}^{-1} \mathrm{month}^{-1}\right)$.

In comparing the average monthly production of total litterfall between the studied coverages, it was observed that Pinus stands did not differ from each other, and presented lower values than those observed in the native forest (Table 3 ). This result indicates that the organization of the forest system (homogeneous or heterogeneous) did not provide differences in the litterfall deposition dynamics of Pinus stands. The same tendency was observed for the monthly depositions of leaves, bark and branches. Hinkel \& Panitz (1999) also found a higher monthly contribution in the native forest area (Mata Atlântica) (530.88 $\mathrm{kg} \mathrm{ha}^{-1} \mathrm{month}^{-1}$ ) when compared to a Pinus elliottii stand (354.17 $\left.\mathrm{kg} \mathrm{ha}^{-1} \mathrm{month}^{-1}\right)$ in Florianópolis (SC).

Total annual litterfall for Pinus in the consortium, Pinus caribaea and native forest were 2.780, 2.406 and $6.497 \mathrm{~kg} \mathrm{ha}^{-1}$, respectively (Table 4). Novais \& Poggiani (1983) observed higher results in Pinus plantations in a homogeneous stand of Pinus caribaea (4.458 $\mathrm{kg} \mathrm{ha}^{-1}$ ) and in a consortium of Pinus caribaea with Liquidambar (5.571 $\mathrm{kg} \mathrm{ha}^{-1}$ ) in the municipality of Agudos (SP). However, in studying a Semi-deciduous Seasonal Forest in a late successional stage in the state of Minas
Gerais, Pinto et al. (2008) found annual production of $8.819 \mathrm{~kg} \mathrm{ha}^{-1}$, a value higher than that observed in the reference forest of the present study.

The leaves fraction represented the greatest proportion of the litterfall in both the Pinus stands and the native forest for all months of the year (Table 4), thus contributing an average of $96.6 \%$ and $72.2 \%$ to the litterfall, respectively (Table 3 ). The mean value of Pinus plantations agrees with those found by Piovesan et al. (2012) (95.6\%) in Pinus taeda stands in the state of Paraná. Several other studies in natural and planted forests have also found that the leaves fraction constitutes the main component of the material deposited on the soil (Schumacher et al., 2003; Pinto et al., 2008; Diniz et al., 2011; Cunha et al., 2013; Antoneli \& Schenemann, 2014; Santos Neto et al., 2015).

The average contribution of the other fractions in the Pinus caribaea and native forest stands followed the order: leaves $>$ branches $>$ bark $>$ reproductive structures. Pezzatto \& Wisniewski (2006) found the same distribution pattern in different succession species of the Semi-deciduous Seasonal Forest in the West of Paraná, and Piovesan et al. (2012) in Pinus taeda stands. The distribution sequence in the consortium Pinus stand was: leaves $>$ reproductive structures $>$ bark $>$ branches.

Based on Table 4, which shows the variation of the total litter production and the fractions throughout the year, it is observed that there was no production of branches in the Pinus stands for most months. According to Collins (1977), the use of collectors can lead to faults in the sampling of the branches fraction, considering that they might not reach the collectors. However, in view of the fact that the branches in Pinus stands are better adhered to the tree trunks when compared to native forest, this may explain the null production of these tree branches in several months of the year.

Table 3. Average monthly litter production in a twelve-month period in three forest ecosystems in southwestern Bahia.

\begin{tabular}{|c|c|c|c|c|c|}
\hline \multirow{2}{*}{ Coverage } & \multicolumn{5}{|c|}{ Litter Fractions $\left(\mathrm{kg} \mathrm{ha}^{-1}\right.$ month $\left.^{-1}\right)$} \\
\hline & Leaves & RS & Bark & Branches & Total \\
\hline Pinus in consortium ${ }^{\star}$ & $225.7(12.9) \mathrm{Ab}$ & $5.0(1.5) \mathrm{Bb}$ & $2.0(0.3) \mathrm{Cb}$ & $1.5(1.4) \mathrm{Cb}$ & $234.2(13.2) \mathrm{b}$ \\
\hline Pinus caribaea & $193.0(13.2) \mathrm{Ab}$ & $0.4(0.4) \mathrm{Bb}$ & $0.7(0.3) \mathrm{Bb}$ & $1.3(0.9) \mathrm{Bb}$ & $195.4(13.4) b$ \\
\hline Native forest & $381.2(16.4) \mathrm{Aa}$ & $14.7(4.6) \mathrm{Ca}$ & $30.2(9.6) \mathrm{Ca}$ & $101.3(11.8) \mathrm{Ba}$ & $527.4(24.7) \mathrm{a}$ \\
\hline
\end{tabular}

${ }^{*}$ Pinus in consortium - Pinus caribaea, Pinus oocarpa, Pinus taeda; RS = Reproductive structures. Values in parentheses correspond to the mean standard error. Averages followed by the same uppercase letters in the line which compare the fractions, and lowercase letters in the column which compare forest ecosystems, do not differ from one another by the Tukey test at $5 \%$ significance. 
Table 4. Monthly production and contribution of different litter forming fractions in a twelve-month period in three forest ecosystems in Southwest Bahia.

\begin{tabular}{|c|c|c|c|c|c|c|c|c|c|}
\hline \multirow{4}{*}{ Month/ Year } & \multicolumn{9}{|c|}{ Litter Fractions } \\
\hline & \multicolumn{2}{|c|}{ Leaves } & \multicolumn{2}{|c|}{ RS } & \multicolumn{2}{|c|}{ Bark } & \multicolumn{2}{|c|}{ Branches } & \multirow{2}{*}{$\frac{\text { Total }}{\text { kg.ha }^{-1}}$} \\
\hline & kg.ha-1 & $\%$ & kg.ha-1 & $\%$ & kg.ha-1 & $\%$ & kg.ha-1 & $\%$ & \\
\hline & \multicolumn{9}{|c|}{ Pinus in consortium* ${ }^{\star}$} \\
\hline June & 384.6 & 97.99 & 6.44 & 1.64 & 0.87 & 0.22 & 0.58 & 0.15 & 392.44 \\
\hline July & 168.1 & 91.13 & 11.85 & 6.43 & 4.51 & 2.44 & 0.00 & 0.00 & 184.44 \\
\hline August & 188.5 & 76.94 & 55.64 & 22.71 & 0.84 & 0.34 & 0.00 & 0.00 & 244.95 \\
\hline September & 234.0 & 95.52 & 9.78 & 3.99 & 1.20 & 0.49 & 0.00 & 0.00 & 245.02 \\
\hline October & 267.4 & 97.25 & 6.51 & 2.37 & 1.05 & 0.38 & 0.00 & 0.00 & 274.98 \\
\hline November & 307.9 & 97.88 & 4.69 & 1.49 & 1.96 & 0.62 & 0.00 & 0.00 & 314.51 \\
\hline December & 215.0 & 97.32 & 2.04 & 0.92 & 3.89 & 1.76 & 0.00 & 0.00 & 220.95 \\
\hline January & 164.6 & 96.10 & 0.56 & 0.33 & 6.12 & 3.57 & 20.40 & 11.91 & 191.88 \\
\hline February & 104.0 & 98.21 & 0.33 & 0.31 & 0.84 & 0.79 & 0.73 & 0.00 & 105.93 \\
\hline March & 188.8 & 99.03 & 0.04 & 0.02 & 1.82 & 0.95 & 0.00 & 0.00 & 190.62 \\
\hline April & 255.5 & 99.59 & 0.95 & 0.37 & 0.11 & 0.04 & 0.00 & 0.00 & 256.51 \\
\hline May & 156.9 & 99.17 & 0.22 & 0.14 & 1.09 & 0.69 & 0.00 & 0.00 & 158.22 \\
\hline \multirow[t]{2}{*}{ Total } & 2635.2 & 94.66 & 99.03 & 3.39 & 24.30 & 0.99 & 21.71 & 0.96 & 2780.23 \\
\hline & \multicolumn{9}{|c|}{ Pinus caribaea } \\
\hline June & 222.6 & 99.30 & 1.03 & 0.46 & 0.53 & 0.24 & 0.00 & 0.00 & 224.13 \\
\hline July & 215.4 & 98.73 & 1.70 & 0.78 & 1.07 & 0.49 & 0.00 & 0.00 & 218.13 \\
\hline August & 135.7 & 95.41 & 0.67 & 0.47 & 0.20 & 0.14 & 5.67 & 3.98 & 142.23 \\
\hline September & 192.3 & 99.59 & 0.63 & 0.33 & 0.17 & 0.09 & 0.00 & 0.00 & 193.07 \\
\hline October & 288.9 & 99.85 & 0.30 & 0.10 & 0.13 & 0.05 & 0.00 & 0.00 & 289.30 \\
\hline November & 243.8 & 99.61 & 0.17 & 0.07 & 0.80 & 0.33 & 0.00 & 0.00 & 244.80 \\
\hline December & 213.6 & 99.49 & 0.50 & 0.23 & 0.60 & 0.28 & 0.00 & 0.00 & 214.70 \\
\hline January & 108.5 & 99.97 & 0.03 & 0.03 & 0.00 & 0.00 & 0.00 & 0.00 & 108.53 \\
\hline February & 79.6 & 98.16 & 0.07 & 0.08 & 0.87 & 1.07 & 0.57 & 0.70 & 81.13 \\
\hline March & 145.4 & 99.75 & 0.13 & 0.09 & 0.23 & 0.16 & 0.00 & 0.00 & 145.77 \\
\hline April & 368.4 & 100.00 & 0.00 & 0.00 & 0.00 & 0.00 & 0.00 & 0.00 & 368.43 \\
\hline May & 162.5 & 92.43 & 0.00 & 0.00 & 3.77 & 2.14 & 9.53 & 5.42 & 175.80 \\
\hline \multirow[t]{2}{*}{ Total } & 2376.7 & 98.52 & 5.23 & 0.22 & 8.37 & 0.41 & 15.77 & 0.84 & 2406.03 \\
\hline & \multicolumn{9}{|c|}{ Native forest } \\
\hline June & 423.2 & 77.62 & 47.50 & 8.71 & 0.00 & 0.00 & 74.50 & 13.66 & 545.20 \\
\hline July & 441.9 & 76.40 & 70.80 & 12.24 & 0.00 & 0.00 & 65.70 & 11.36 & 578.40 \\
\hline August & 699.4 & 78.06 & 24.40 & 2.72 & 17.90 & 2.00 & 154.30 & 17.22 & 896.00 \\
\hline September & 556.5 & 75.74 & 0.00 & 0.00 & 84.80 & 11.54 & 93.47 & 12.72 & 734.80 \\
\hline October & 835.2 & 68.87 & 0.00 & 0.00 & 130.80 & 10.79 & 246.67 & 20.34 & 1212.67 \\
\hline November & 194.0 & 75.86 & 0.13 & 0.05 & 2.40 & 0.94 & 59.20 & 23.15 & 255.73 \\
\hline December & 507.9 & 87.99 & 0.00 & 0.00 & 2.00 & 0.35 & 67.33 & 11.67 & 577.20 \\
\hline January & 114.5 & 58.39 & 2.60 & 1.33 & 5.40 & 2.75 & 73.60 & 37.53 & 196.10 \\
\hline February & 132.1 & 27.21 & 0.40 & 0.08 & 64.80 & 13.35 & 288.20 & 59.36 & 485.50 \\
\hline March & 152.8 & 75.79 & 8.50 & 4.22 & 0.90 & 0.45 & 39.40 & 19.54 & 201.60 \\
\hline April & 217.0 & 87.01 & 7.10 & 2.85 & 0.10 & 0.04 & 25.20 & 10.10 & 249.40 \\
\hline May & 442.5 & 78.47 & 0.00 & 0.00 & 78.30 & 13.89 & 43.10 & 7.64 & 563.90 \\
\hline Total & 4717.0 & 72.28 & 161.43 & 2.68 & 387.40 & 4.67 & 1230.67 & 20.36 & 6496.50 \\
\hline
\end{tabular}

${ }^{\star}$ Pinus in consortium - Pinus caribaea, Pinus oocarpa, Pinus taeda; RS = Reproductive structures.

\subsection{Temporal variation of litterfall production}

The maximum contribution of total litter occurred in June for the Pinus consortium stand, and in April for Pinus caribaea (Table 4). The maximum contribution in the native forest occurred in October, with a decrease after this month (Table 4). Such distribution characterizes a typical seasonal pattern of semi-deciduous seasonal forests, in which the peak leaf deposition occurs at the end of the dry season (August-October) as the vegetation's response to the climatic seasonality (Werneck et al., 2001; Arato et al., 2003; Santos Neto et al., 2015). 
When the data regarding the monthly litter production (total and fractions) was correlated with the climatic variables, significant associations were only found between the branches fraction and the wind speed in the native forest; between the reproductive structures (RS) fraction with relative humidity (positive correlation) in the native forest and in the Pinus in consortium; and with temperature (negative correlation) in all forest ecosystems studied (Table 5). These results indicate that the largest deposition of the reproductive structures occurred during the period of lower temperatures and higher humidity. This observation is consistent with a study carried out by Piovesan et al. (2012) in Pinus taeda in the state of Paraná; by König et al. (2002) in Deciduous Seasonal Forest in Rio Grande do Sul, who found negative coefficients between temperature and the production of reproductive structures; and by Vieira \& Shumacher (2010a) for Pinus taeda in
Cambará do Sul (RS), who found a positive correlation between the deposition of reproductive structures and relative humidity.

\subsection{Rate of litter decomposition}

The average amounts of accumulated litter observed in Pinus stands were lower than the value found in native forest (Table 6). Higher accumulations were verified by Carvalho et al. (2008) in Pinus elliottii stands (18.000 $\mathrm{kg} \mathrm{ha}^{-1}$ ), and by Lima et al. (2015) in Pinus oocarpa stands (15.267 $\mathrm{kg} \mathrm{ha}^{-1}$ ) over 30 years of age.

The coefficient of litter decomposition (K) did not significantly vary among the studied stands (Table 6), which shows that they are not distinguishable as to the decomposition speed of their vegetation residues. However, low decomposition rates are usually observed in Pinus stands (Melo \& Resck, 2002; Ribeiro et al., 2007;

Table 5. Correlation coefficient between the monthly variation of litter production and meteorological variables.

\begin{tabular}{|c|c|c|c|c|c|}
\hline \multirow{3}{*}{ Climate Variables } & \multicolumn{5}{|c|}{ Litter Fractions } \\
\hline & Leaves & RS & Bark & Branches & Total \\
\hline & \multicolumn{5}{|c|}{ Pinus in consortium } \\
\hline Precipitation & 0.10 & -0.29 & 0.45 & 0.09 & 0.09 \\
\hline Average temperature & 0.15 & $-0.66^{*}$ & 0.11 & 0.13 & 0.11 \\
\hline Wind speed & -0.20 & 0.12 & -0.15 & 0.17 & -0.19 \\
\hline \multirow{2}{*}{ Relative humidity } & 0.08 & $0.61^{*}$ & 0.15 & -0.01 & 0.12 \\
\hline & \multicolumn{5}{|c|}{ Pinus caribaea } \\
\hline Precipitation & -0.04 & -0.25 & 0.34 & 0.09 & -0.09 \\
\hline Average temperature & 0.47 & $-0.56^{*}$ & 0.02 & 0.14 & 0.36 \\
\hline Wind speed & 0.03 & 0.37 & -0.13 & 0.19 & 0.10 \\
\hline \multirow[t]{2}{*}{ Relative humidity } & -0.49 & 0.29 & 0.12 & -0.03 & -0.43 \\
\hline & \multicolumn{5}{|c|}{ Native forest } \\
\hline Precipitation & 0.01 & -0.27 & -0.25 & -0.18 & -0.10 \\
\hline Average temperature & -0.42 & $-0.72^{*}$ & -0.11 & -0.33 & -0.48 \\
\hline Wind speed & 0.15 & -0.30 & 0.44 & $0.58^{*}$ & 0.32 \\
\hline Relative humidity & 0.30 & $0.78^{\star}$ & -0.19 & 0.11 & 0.29 \\
\hline
\end{tabular}

* significant correlations at $5 \%$ significance.

Table 6. Decomposition constant $(\mathrm{K})$, litter renewal time and litter half-life $\left(\mathrm{T}_{1 / 2}\right)$ of three forest ecosystems in southwestern Bahia.

\begin{tabular}{|c|c|c|c|c|}
\hline Cover & Accumulation & $\mathbf{K}$ & $\mathrm{T}_{\mathrm{R}}$ & $\mathrm{T}_{0.5}$ \\
\hline & $\mathrm{kg} \mathrm{ha}^{-1}$ & & \multicolumn{2}{|c|}{---- years ---- } \\
\hline Pinus in consortium ${ }^{\star}$ & $3590.95(215.3) b$ & $0.77(0.09) \mathrm{a}$ & $1.29(0.13)$ & $0.90(0.09)$ \\
\hline Pinus caribaea & $2822.40(207.0) \mathrm{b}$ & $0.85(0.37) \mathrm{a}$ & $1.17(0.12)$ & $0.81(0.08)$ \\
\hline Native forest & $6385.20(399.0) \mathrm{a}$ & $1.02(0.12) \mathrm{a}$ & $0.98(0.15)$ & $0.68(0.11)$ \\
\hline
\end{tabular}

${ }^{*}$ Pinus in consortium - Pinus caribaea, Pinus oocarpa, Pinus taeda; $\mathrm{K}=$ decomposition constant; $\mathrm{T}_{\mathrm{R}}=$ litter renewal time; $\mathrm{T}_{0.5}=$ half-life time. Values in parentheses correspond to the mean standard error. Means followed by the same letter in the column do not differ from one another by the Tukey test at $5 \%$ significance. 
Carvalho et al., 2008), which are generally attributed to the chemical composition of the plant material and presents high levels of phenolic compounds and lignin and/or a higher C/N ratio (Moreira \& Siqueira, 2002).

Morellato (1992), Schlittler et al. (1993) and Pimenta et al. (2011) recorded K coefficients ranging from 1.02 to 2.45 in fragments of Semi-deciduous Seasonal Forest. In addition to the quality of plant residues, variations in the litter decomposition speed among forest stands may be related to the type of vegetation cover, to the fauna activity of the soil (Anderson et al., 1983) and to environmental conditions (Silva et al., 2014).

The average time for litter renewal $\left(T_{R}\right)$ in Pinus stands was 1.2 years (Pinus caribaea) and 1.3 years (Pinus in consortium), while it was 0.98 years in the native forest (Table 6). According to Vogt et al. (1986) and Melo \& Resck, (2002), $\mathrm{T}_{\mathrm{R}}$ values in tropical deciduous and semi-deciduous hardwood forests are usually observed as being less than one year, while this time is greater than one year in the case of conifers (Pinus).

The time required for $50 \%$ litter decomposition $\left(\mathrm{T}_{1 / 2}\right)$ to occur was estimated at 0.90 years (329 days) for Pinus in consortium, 0.81 years (296 days) for Pinus caribaea, and 0.68 years (248 days) for the native forest. Cunha et al. (2013) and Lopes et al. (2009) found $\mathrm{T}_{1 / 2}$ of 0.73 and 0.98 years for Semi-deciduous Seasonal Forest in secondary succession in the state of Minas Gerais and for the Caatinga in Ceará, respectively.

\section{CONCLUSION}

1. Litterfall production is similar for both Pinus stands, which allows for inferring that the organization of the forest system (homogeneous or heterogeneous) did not interfere in litterfall contribution dynamics. On the other hand, these values are inferior to those found in the reference forest and in stands of the same genus in other regions of Brazil, thus showing lower potential for litter accumulation.

2. The litter produced was mostly composed of leaves; about $97 \%$ in the Pinus stands, and $72 \%$ in the native forest.

3. The temporal variation of litter supply is not very sensitive to variations in climate, with a greater influence of the temperature and relative air humidity in the deposition of reproductive structures.

4. The litter decomposition speed is similar for the Pinus stands and the native forest. However, the average litter renewal time is over one year in Pinus stands (mean of 1.25 years), and less than one year in the native forest ( 0.98 years).

\section{SUBMISSION STATUS}

Received: 16 apr., 2016

Accepted: 26 oct., 2017

\section{CORRESPONDENCE TO}

\section{Flávia Ferreira de Carvalho}

Departamento de Engenharia Agrícola e Solos, Universidade Estadual do Sudoeste da Bahia UESB, Estrada do Bem Querer, s/n, CEP 45083900, Vitoria da Conquista, BA, Brasil e-mail: carvalho.f.flavia@gmail.com

\section{FINANCIAL SUPPORT}

FAPESB, bolsa de iniciação científica, $\mathrm{n}^{\circ}$ de outorga: $1925 / 2013$.

\section{REFERENCES}

Associação Brasileira de Produtores de Florestas Plantadas - ABRAF. Anuário estatístico da ABRAF 2013 ano base 2012. Brasília: ABRAF; 2013. 130 p. [cited 2015 Set 20]. Available from: http://www.bibliotecaflorestal.ufv.br/ handle/123456789/3910.

Anderson JM, Proctor J, Vallack HW. Ecological studies in four constrasting lowland rain forest in Gunung Mulu National Park, Sarawak. III. Decomposition processes and nutrient losses from leaf litter. Journal of Ecology 1983; 71(2): 503-527. http://dx.doi.org/10.2307/2259731.

Andrade AG, Costa GS, Faria SM. Deposição e decomposição da serapilheira em povoamentos de Mimosa caesalpiniifolia, Acacia manguim e Acacia holosericea com quatro anos de idade em planossolo. Revista Brasileira de Ciência do Solo 2000; 24(4): 777-785. http://dx.doi.org/10.1590/ S0100-06832000000400010.

Antoneli V, Schenemann R. Influência de alguns elementos climáticos na deposição de serapilheira no cultivo de erva mate (Ilex paraguariensis) na região sudeste do Paraná. Revista Brasileira de Geografia Física 2014; 7(3): 486-496.

Arato HD, Martins SV, Ferrari SHS. Produção e decomposição de serapilheira em um sistema agroflorestal implantado para 
recuperação de área degradada em Viçosa - MG. Revista Árvore 2003; 27(5): 715-721. http://dx.doi.org/10.1590/ S0100-67622003000500014.

Barbosa VA, Barreto-Garcia PAB, Gama-Rodrigues EF, Paula A. Biomassa, carbono e nitrogênio na serapilheira acumulada de florestas plantadas e nativa. Floram 2017; 24(1): 1-9.

Brasil. Conselho Nacional do Meio Ambiente - CONAMA. Resolução $n^{\circ} 1$, de 31 de janeiro de 1994. Define vegetação primária e secundária nos estágios pioneiro, inicial, médio e avançado de regeneração da Mata Atlântica . Diário Oficial da União, Brasília, DF (1994 jan. 31); Sec. 1: 1684-1685.

Carvalho AMX, Vale HMM, Ferreira EM, Cordero AFP, Barros NF, Costa MD. Atividade microbiana de solo e serapilheira em áreas povoadas com Pinus elliottii e Terminalia ivorensis. Revista Brasileira de Ciência do Solo 2008; 32(spe): 2709-2716. http://dx.doi.org/10.1590/ S0100-06832008000700014.

Chaves RQ, Corrêa GF. Macronutrientes no sistema solo-Pinus caribaea Morelet em plantios apresentando amarelecimento das acículas e morte de plantas. Revista Árvore 2005; 29(5): 691-700. http://dx.doi.org/10.1590/ S0100-67622005000500004.

Collins NM. Vegetation and litter production in Southern Guinea Savanna, Nigeria. Oecologia 1977; 28(2): 163-175. http://dx.doi.org/10.1007/BF00345252. PMid:28309015.

Cunha FV No, Leles PSS, Pereira MG, Bellumath VGH, Alonso JM. Acúmulo e decomposição da serapilheira em quatro formações florestais. Ciência Florestal 2013; 23(3):379-387.

Diniz AR, Pereira MG, Loss A. Aporte de material decíduo e nutrientes para o solo em plantio de eucalipto e floresta secundária. Pesquisa Florestal Brasileira 2011; 31(65): 1926. http://dx.doi.org/10.4336/2011.pfb.31.65.19.

Empresa Brasileira de Pesquisa Agropecuária - EMBRAPA. Embrapa Florestas Sistemas de Produção. [cited 2014 mai. 10]. Available from: https://www.spo.cnptia.embrapa. br/conteudo?p_p_id=conteudoportlet_WAR_sistemas deproducaolf6_1ga1ceportlet\&p_p_lifecycle=0\&p_p_ state $=$ normal\&p_p_mode $=$ view\&p_p_col_id $=$ column2\&p_p_col_count=1\&p_r_p_-76293187_sistemaProdu caoId=3715\&p_r_p_-996514994_topicoId=3228

Empresa Brasileira de Pesquisa Agropecuária - EMBRAPA. Serviço Nacional de Levantamento e Conservação de Solos. Manual de métodos de análise de solo. 2nd ed. Rio de Janeiro: SNLCS; 1997.

Gama-Rodrigues AC, Barros NF. Ciclagem de nutrientes em floresta natural e em plantios de eucalipto e de dandá no sudeste da Bahia, Brasil. Revista Árvore 2002; 26(2): 193-207.

Giácomo RG, Pereira MG, Machado DL. Aporte e decomposição de serapilheira em áreas de Cerradão e Mata Mesofítica na Estação Ecológica de Pirapitinga -
MG. Ciência Florestal 2012; 22(4): 669-680. http://dx.doi. org/10.5902/198050987549.

Godinho TO, Aldeira MVW, Caliman JP, Prezotti LC, Watzlawick LF, Azevedo HCA et al. Biomassa, macronutrientes e carbono orgânico na serapilheira depositada em trecho de floresta Estacional Semidecidual Submontana, ES. Scientia Forestalis 2013; 41(97): 131-144.

Hinkel R, Panitz CMN. Estudo comparativo da produção de serapilheira de uma área de Mata Atlântica e de um povoamento de Pinus elliottii Engelm. Var. elliottii na Ilha de Santa Catarina, Brasil. Biotemas 1999; 12(1): 67-93.

Indústria Brasileira de produtores de Árvores - IBÁ. Relatório IBÁ 2015 ano base 2014. Brasília; 2015. 64 p. Disponível em: <http://www.iba.org/images/shared/ iba_2015.pdf>. Acesso em: 20 jun. 2017.

Instituto Brasileiro de Geografia e Estatística - IBGE. Manual técnico da vegetação brasileira. 2. ed. Rio de Janeiro: IBGE; 2012. 271 p.

König FG, Schumacher MV, Brun EJ, Seling I. Avaliação da sazonalidade da produção de serapilheira numa floresta estacional decidual no município de Santa Maria - RS. Revista Árvore 2002; 26(4): 429-435. http://dx.doi. org/10.1590/S0100-67622002000400005.

Lima NL, Silva-Neto CM, Calil FN, Souza KR, Moraes DC. Acúmulo de serapilheira em quatro tipos de vegetação no estado de Goiás. Enciclopédia Biosfera 2015; 11(22): 39-46. http://dx.doi.org/10.18677/Enciclopedia_Biosfera_2015_068.

Lopes JFB, Andrade EM, Lobato FAO, Palácio HAQ, Arraes FDD. Deposição e decomposição de serapilheira em área da Caatinga. Revista Agro Ambiente 2009; 3(2): 72-79. http://dx.doi.org/10.18227/1982-8470ragro.v3i2.252.

Mateus FA, Miranda CC, Valcarcel R, Figueiredo PHA. Estoque e capacidade de retenção hídrica da serrapilheira acumulada na restauração florestal de áreas perturbadas na Mata Atlântica. Floresta e Ambiente 2013; 20(3): 336-343.

Medeiros GIB, Florindo TJ, Schultz G, Talamini E. Análise da competitividade da cadeia produtiva de oleresina de Pinus Brasileira. Revista Espacios 2017; 38(27): 29.

Melo JT, Resck DVS. Retorno, ao solo, de nutrientes de serapilheira de Pinus no cerrado do Distrito Federal. Planaltina: Embrapa Cerrados; 2002. 18 p.

Moreira FM, Siqueira JO. Microbiologia e bioquímica do solo. Lavras: Editora UFLA; 2002. 626 p.

Morellato LPC. Nutrient cycling in two south-east Brazilian forests. I Litterfall and litter standing crop. Journal of Tropical Ecology 1992; 8(2): 205-215. http:// dx.doi.org/10.1017/S0266467400006362.

Novais RFF, Poggiani F. Deposição de folhas e nutrientes em plantações florestais puras e consorciadas de Pinus e Liquidambar. IPEF 1983; 23: 57-60. 
Olson JS. Energy storage and the balance of producers in ecological systems. Ecology 1963; 44(2): 322-331. http:// dx.doi.org/10.2307/1932179.

Pezzatto A, Wisniewski C. Produção de serapilheira em diferente seres sucessionais da floresta estacional semidecidual no oeste do Paraná. Revista Floresta 2006; 36(1): 111-120.

Pimenta JA, Rossi LB, Torezan JMD, Cavalheiro AL, Bianchini E. Produção de serapilheira e ciclagem de nutrientes de um reflorestamento e de uma floresta estacional semidecidual no sul do Brasil. Acta Botanica Brasílica 2011; 25(1): 53-57. http://dx.doi.org/10.1590/ S0102-33062011000100008.

Pinto SIC, Martins SV, Barros NF, Dias HCT. Produção de serapilheira em dois estádios sucessionais de Floresta Estacional Semidecidual na Reserva Mata do Paraíso, em Viçosa, MG. Revista Árvore 2008; 32(3): 545-556. http:// dx.doi.org/10.1590/S0100-67622008000300015.

Pinto HCA, Barreto-Garcia PAB, Gama-Rodrigues EF, Oliveira FGRB, Paula A, Amaral AR. Decomposição da serapilheira foliar de floresta nativa e plantios de Pterogyne nitens e Eucalyptus urophylla no Sudoeste da Bahia. Ciência Florestal 2016; 26(4): 1141-1153. http:// dx.doi.org/10.5902/1980509825105.

Piovesan G, Schumacher MV, Vieira M, Lopes VG, Weter C. Deposição de serapilheira em povoamento de pinus. Pesquisa Agropecuária 2012; 42(2): 206-211. http://dx.doi. org/10.1590/S1983-40632012000200012.

Poggiani F, Zamberlan R, Gava EM, Gava IC. Quantificação da deposição de folhedo em talhões experimentais de Pinus taeda, Eucalyptus viminalis e Mimosa scabrella plantados em uma área degradada pela mineração do xisto betuminoso. IPEF 1987; 37: 21-29.

Ribeiro C, Cortez N, Martins A, Azevedo A, Madeira M. Decomposição de agulhas de Pinus pinaster e de folhas de Eucalyptus globulus em regiões do interior e do litoral de Portugal. Revista de Ciências Agrárias 2007; 30(2): 144-158.

Santos HG, Jacomine PKT, Anjos LHC, Oliveira VA, Oliveira JB, Coelho MR et al. Sistema brasileiro de classificação de solos. 2. ed. Rio de Janeiro: Embrapa Solos; 2006. 306 p.

Santos Neto AP, Barreto PAB, Gama-Rodrigues EF, Novaes AB, Paula A. Produção de serapilheira em Floresta Estacional Semidecidual e em plantios de Pterogyne nitens Tul. e Eucalyptus urophylla S. T. Blake no Sudoeste da Bahia. Ciência Florestal 2015; 25(3): 631-641. http:// dx.doi.org/10.5902/1980509819614.

Schlittler FHM, Marinis G, César O. Decomposição da serapilheira produzida na floresta do Morro do Diabo (região do Pontal do Paranapanema, Estado de São Paulo). Naturalia 1993; 18: 149-156.

Schumacher MV, Brun EJ, Rodrigues LM, Santos EM. Retorno de nutrientes via deposição de serapilheira em um povoamento de acácia-negra (Acacia mearnsii De Wild.) no estado do Rio Grande do Sul. Revista Árvore 2003; 27(6): 791-798. http://dx.doi.org/10.1590/S010067622003000600005 .

Schumacher MV, Viera M, Witschoreck R. Produção de serapilheira e transferência de nutrientes em área de segunda rotação com floresta de Pinus taeda L. no município de Cambará do Sul, RS. Ciência Florestal 2008; 18(4): 471-480. http://dx.doi.org/10.5902/19805098431.

Shanks R, Olson JS. First year breakdown of leaf litter in Southern Appalachia. Forest Science 1961; 134(3473): 194-195. PMid:17818719.

Silva HF, Barreto PAB, Sousa GTO, Azevedo GB, GamaRodrigues EF, Oliveira FGRB. Decomposição de serapilheira foliar em três sistemas florestais no Sudoeste da Bahia. Revista Brasileira de Biociências 2014; 12(3): 164-172.

Vieira M, Shumacher MV. Variação mensal da deposição de serapilheira em povoamento de Pinus taeda L. em área de campo nativo em Cambará do Sul-RS. Revista Árvore 2010a; 34(3): 487-494. http://dx.doi.org/10.1590/S010067622010000300012 .

Vieira M, Shumacher MV. Teores e aporte de nutrientes na serapilheira de Pinus taeda L., e sua relação com a temperatura do ar e pluviosidade. Revista Árvore 2010b; 34(1): 85-94. http://dx.doi.org/10.1590/S010067622010000100010 .

Vogt KA, Grier CC, Vogt DJ. Production, turnover and nutrient dynamics of above- and below-ground detritus of world forests. Advances in Ecological Research 1986; 15: 303-366. http://dx.doi.org/10.1016/S0065-2504(08)60122-1.

Werneck MS, Pedralli G, Gieseke LF. Produção de serapilheira em três trechos de uma floresta semidecídua com diferentes graus de perturbação na Estação Ecológica do Tripuí, Ouro Preto-MG. Revista Brasileira de Botanica. Brazilian Journal of Botany 2001; 24(2): 195-198. http:// dx.doi.org/10.1590/S0100-84042001000200009. 